\title{
"Yutu Gisel" Sebagai Media Pembelajaran untuk Meningkatkan Aktivitas dan Hasil Belajar Biologi Sel
}

\author{
I Gusti Putu Sunaya ${ }^{1}$ \\ ${ }^{1}$ SMA Negeri 1 Kuta Selatan, \\ Badung, Indonesia \\ e-mail: ngis.sunaya@gmail.com ${ }^{1}$
}

\begin{abstract}
Abstrak
Yutu Gisel adalah akronim dari "Youtube Biologi Sel.com" yang merupakan strategi pemecahan masalah guru dengan menggunakan media pembelajaran untuk meningkatkan aktivitas dan hasil belajar biologi tentang "Sel" siswa Kelas XI-MIPA di SMA Negeri 1 Kuta Selatan. Youtobe Biologi Sel.com sebagai media pembelajaran Biologi Sel di kelas XI dengan materi pokok biologi sel; 1) komponen kimiawi penyusun sel, 2) struktur dan fungsi bagianbagian sel, 3) kegiatan sel sebagai unit struktural dan fungsional makhluk hidup, 4) tranpor membrane, 5) sintesis protein untuk menyusun sifat morfologis dan fisiologis sel, dan 6) reproduksi sel sebagai kegiatan untuk membentuk morfologi tubuh dan memperbanyak tubuh. Data hasil penelitian berupa data hasil belajar siswa dikumpulkan dengan menggunakan tes hasil belajar/ulangan formatif, sedang aktivitas belajar siswa dikumpulkan dengan blanko observasi tipe likert skala lima, dengan masing-masing kriteria penilaian : sangat aktif, aktif, cukup aktif, kurang aktif, sangat kurang aktif dengan dianalisis secara deskriptif. Dengan penggunaan media Youtobe Biologi Sel.com dapat ditemukan bahwa kombinasi Yout.com dapat meningkatkan aktivitas dan hasil belajar pada Pelajaran Biologi Sel Siswa Kelas XI MIPA Semester I SMA Negeri 1 Kuta Selatan sejak Tahun Pelajaran 2017/2018 sampai dengan Tahun Pelajaran 2019/2020.
\end{abstract}

Kata-kata kunci: youtobe biologi sel.com, aktivitas, hasil belajar.

\begin{abstract}
Yutu Gisel is an acronym for "Youtube Biologi Sel.com" which is a teacher problem solving strategy by using instructional media to increase the activities and learning outcomes of biology about "Cell" Class XI-MIPA students in SMA Negeri 1 Kuta Selatan. Youtobe Biology Sel.com as a learning medium for Cell Biology in class XI with the subject matter of cell biology; 1) the chemical components of cells, 2) the structure and function of cell parts, 3) cell activities as structural and functional units of living things, 4) membrane transport, 5) protein synthesis to compile cell morphological and physiological properties, and 6) reproduction cells as activities to form the body's morphology and reproduce the body. The research data in the form of student learning outcomes data were collected using formative learning / test results, while student learning activities were collected with a five-scale Likert type observation blank, with each rating criteria: very active, active, quite active, less active, very less active by being analyzed descriptively. With the use of the Youtobe Biology media Sel.com it can be found that the combination of Yout.com can increase the activity and learning outcomes in the Cell Biology Lesson of Class XI MIPA Students Semester 1 SMA Negeri Kuta Selatan since the Academic Year 2017/2018 until the 2019/2020 Academic Year.
\end{abstract}

Keywords: youtobe biology sel.com, activities, learning outcomes.

\section{Pendahuluan}

Input sumber daya meliputi sumber daya manusia (kepala sekolah, guru, konselor, karyawan, dan peserta didik), dan sumber daya yang lain berupa (peralatan, perlengkapan, uang, bahan, dan sebagainya). Input perangkat lunak meliputi (sruktur organisasi sekolah, peraturan perundang-undangan, deskripsi tugas, rencana program, dan sebagainya). Sedangkan input harapan-harapan berupa (visi, misi, tujuan, dan sasaran-sasaran yang ingin dicapai oleh sekolah). Kesiapan input sangat diperlukan agar proses dapat berlangsung dengan baik, oleh karena itu tinggi rendahnya mutu input dapat diukur dari kesiapan input. 
Proses pendidikan merupakan berubahnya sesuatu menjadi sesuatu yang lain. Sesuatu yang berpengaruh terhadap berlangsungnya proses disebut input, sedangkan sesuatu dari hasil proses disebut output. Dalam pendidikan berskala mikro (tingkat sekolah), proses yang dimaksud adalah proses pengambilan keputusan, proses pengelolaan kelembagaan, proses pengelolaan program, proses belajar mengajar, dan proses monitoring dan evaluasi, dengan catatan bahwa proses belajar mengajar memiliki tingkat kepentingan yang tertinggi dibandingkan dengan proses-proses yang lain. Proses dikatakan bermutu tinggi apabila pengkoordinasian dan penyerasian serta pemaduan input sekolah (guru, siswa, kurikulum, uang, peralatan, dan sebagainya) dilakukan secara harmonis, sehingga mampu menciptakan situasi pembelajaran yang nikmat (enjoyable learning), mampu mendorong motivasi dan minat belajar siswa, dan benar-benar mampu memberdayakan peserta didik. Peserta didik tidak sekadar menguasai pengetahuan yang diajarkan gurunya, akan tetapi pengetahuan tersebut juga telah menjadi muatan nurani peserta didik, dihayati, diamalkan dalam kehidupan seharihari, dan yang lebih penting lagi peserta didik tersebut mampu belajar cara belajar (mengembangkan diri).

Output pendidikan adalah merupakan kinerja sekolah. Kinerja sekolah adalah prestasi sekolah yang dihasilkan dari proses perilaku sekolah yang dapat diukur dari kualitasnya, efektivitasnya, produktivitasnya, efisiensinya, inovasinya, kualitas kehidupan kerjanya, dan moral kerjanya. Output sekolah dapat dikatakan berkualitas atau bermutu tinggi jika prestasi sekolah, khususnya prestasi peserta didik menunjukkan pencapaian yang tinggi dalam : (1) hasil tes kemampuan akademik, berupa nilai ulangan umum, EBTA, NUN, UMPTN; dan (2) prestasi di bidang lain, seperti prestasi olahraga, kesenian, keterampilan, dan mengarang. Mutu sekolah dipengaruhi oleh banyak tahapan kegiatan yang saling berhubungan (proses), seperti misalnya perencanaan, pelaksanaan, dan pengawasan.

Tidak hanya itu, outcome dari pendidikan juga dapat dijadikan sebagai suatu tolok ukur yang tinggi dalam peradaban suatu bangsa, karena dari suatu proses pendidikanlah maju mundurnya bangsa dapat dinilai. Dengan kata lain pendidikan merupakan salah satu investasi untuk meletakkan dasar bagi kejayaan bangsa di masa depan. Untuk mencapai prestasi peserta didik yang tinggi, maka berbagai upaya dilakukan oleh penyelenggara pendidikan, baik dalam bidang kelengkapan sarana dan prasarana, perbaikan manajemen pendidikan, peningkatan kualitas tenaga pengajar, maupun dalam proses pembelajaran.

Pembelajaran Biologi dengan materi Sel di kelas XI MIPA memiliki karakter tingkat kesulitan yang tinggi karena mengkaji tentang; 1 )"bentuk ruang dan struktur bangun" sebuah sel yang umumnya mikroskopik, 2) fungsi bagian-bagian dari sel, 3) komposisi kimia dan reaksi kimia sel, 4) perbanyakan diri sel (reproduksi sel). Dalam proses pembelajaran keseluruhan karakter materi sel tersebut memerlukan media ruang, gambar 3 dimensi atau animasi reaksi-reaksi molekuler untuk mempermudah pemahaman peserta didik.

Sehubungan dengan hal tersebut perlu melakukan inovasi dalam proses pembelajaran. Pembelajaraan merupakan suatu kegiatan yang melibatkan seseorang dalam upaya memperoleh pengetahuan, ketrampilan dan nilai-nilai positif dengan memanfaatkan berbagai sumber untuk belajar. Pembelajaran dapat melibatkan dua pihak yaitu siswa sebagai pembelajar dan guru sebagai fasilitator. Kaitannya bahwa belajar membutuhkan interaksi, hal ini menunjukkan bahwa proses pembelajaran merupakan proses komunikasi, artinya didalamnya terjadi proses penyampaian pesan dari seseorang (sumber pesan) kepada seseorang atau sekelompok orang (penerima pesan). Pesan yang dikirim biasanya berupa informasi atau keterangan yang diubah dalam bentuk sandi-sandi atau lambang-lambang seperti kata-kata, bunyi-bunyi, gambar-gambar. Pesan diterima oleh si penerima pesan melalui indera untuk diolah, sehingga pesan yang disampaikan oleh penyampai pesan dapat diterima dan dipahami oleh penerima pesan ( peserta didik ). Faktor yang dapat menyebabkan pesan tidak dapat dipahami dengan baik karena adanya noise dan barier antara guru dan peserta didik. Baik buruknya kualitas komunikasi untuk mengurangi gangguan (noise) dan hambatan (barier) dalam berkomunikasi diperlukan bantuan media pembelajaran.

Keberhasilan pembelajaran di pandang sebagai keberhasilan proses komunikasi ditentukan oleh banyak faktor seperti guru, murid, metode, alat atau prasarana dan situasi mengajar. Guru dituntut dapat berperan aktif sebagai fasilitator dan mediator dalam menuntun siswa belajar, sehingga dapat mencapai tujuan pengajaran yang diharapkan. Guru senantiasa diharapkan mengembangkan strategi pembelajaran, serta memilih media pembelajaran sehingga pemahaman siswa terhadap materi pelajaran menjadi relatif lebih baik. Berbagai media pembelajaran tersedia dilingkungan pembelajaran; apakah karena kreatifitas guru, peserta didik ataupun telah tersedia di lingkungan belajarnya. 
Guru masa depan dalam kegiatan pembelajaran dapat berfungsi sebagai seniman (artist) dan ilmuwan (scientist) dalam merancang dan melaksanakan pembelajaran dan mengelola sumber-sumber belajar yang sengaja dirancang dan dimanfaatkan. Oleh karena itu diperlukan pengetahuan, sikap, dan keterampilan guru dalam merancang pembelajaran terutama dalam penggunaan media pembelajaran yang berbasis computer dikombinasikan dengan sumber yang bersifat Offline maupun Online. Kenyataan yang ada saat ini selain berkembang kemajuan teknologi di bidang komputer, pula diikuti dengan perkembangan media informasi khususnya Handphone mobile yang berbasis android.

Youtube.com adalah sebuah situs webvideo sharing (berbagi video) populer dimana para pengguna dapat memuat, menonton, dan berbagi klip video secara gratis. Umumnya videovideo di YouTube adalah klip musik (video klip), termasuk video streaming media pembelajaran Biologi. Keberadaan siswa kelas XI MIPA sejak tahun pelajaran 2017/2018 telah menggunakan Handphone mobile berbasis android. Penggunaan Handphone mobile oleh siswa lebih sering untuk bermain dan berkomunikasi dengan teman atau sejawatnya. Fasilitas Handphone mobile seyogyanya pula digunakan sebagai sarana pembelajaran atau sumber belajar khususnya pada mata pelajaran biologi. Selain penggunaan Handphone mobile oleh siswa adanya aplikasi Youtobe.com dalam penyediaan layanan video pembelajaran Biologi namun pemanfaatannya bagi siswa sebagai sumber pembelajaran.

Selain hal di atas kesiapan sarana prasarana di SMA Negeri 1 Kuta Selatan telah tersedia fasilitas wifi yang dapat di-acccess di lingkungan sekolah. Nilai hasil belajar dua tahun pelajaran 2015/2016 dan tahun pelajaran 2016/2017 pada materi pokok "Sel" tertera dalam tabel berikut.

Tabel 01. Perolehan Nilai Tes Kompetensi Kelas XI-MIIPA pada materi pokok "Sel", Tahun Pelajaran 2015/2016 dan Tahun Pelajaran 2016/2017

\begin{tabular}{llllll}
\hline No & $\begin{array}{l}\text { Tahun } \\
\text { Pelajaran }\end{array}$ & $\begin{array}{l}\text { Kelas } \\
\text { XI }\end{array}$ & $\begin{array}{l}\text { Nilai } \\
\text { Minimum }\end{array}$ & $\begin{array}{l}\text { Nilai } \\
\text { Maksimum }\end{array}$ & $\begin{array}{l}\text { Nilai } \\
\text { Rerata }\end{array}$ \\
\hline 1 & $2015 / 2016$ & MIPA-5 & 79 & 97 & 91.82 \\
& & MIPA-6 & 80 & 97 & 93.15 \\
2 & $2016 / 2017$ & MIPA-7 & 80 & 98 & 93.70 \\
\hline
\end{tabular}

Berdasarkan data tersebut di atas diketahui bahwa adanya fluktuasi nilai belajar. Sehingga perlu adanya inovasi pembelajaran untuk menyelesaikan permasalahan pembelajaran biologi sel antara lain ; 1) penggunaan media audio visual berbasis computer masih sangat terbatas; materi biologi kurang menekankan penemuan sendiri sehingga siswa tidak dapat membangun pengetahuannnya sendiri; 3) siswa masih menganggap pelajaran Biologi pelajaran yang menghafal yang membosankan sehingga mengakibatkan keaktifan siswa rendah.

Sardiman (2011: 97) menjelaskan aktivitas dalam belajar memiliki prinsip-prinsip, dalam hal ini dilihat dari sudut pandang perkembangan konsep jiwa menurut IImu Jiwa. Prinsip aktivitas belajar dari sudut pandang ilmu jiwa ini secara garis besar dibagi menjadi dua pandangan yaitu IImu Jiwa Lama dan IImu Jiwa Modern. Menurut IImu Jiwa Lama, dalam proses pembelajaran guru yang mendominasi kegiatan, peserta didik terlalu pasif sedangkan guru aktif dan segala inisiatif datang dari guru. Aktivitas siswa terbatas pada mendengarkan, mencatat, dan menjawab pertanyaan bila guru ceramah dan memberikan pertanyaan selama proses pembelajaran. Proses belajar semacam ini jelas tidak mendorong peserta didik untuk berpikir dan beraktivitas. Sedangkan menurut pandangan IImu Jiwa Modern di mana secara alami siswa menjadi aktif karena adanya motivasi dan didorong oleh bermacam-macam kebutuhan. Guru hanya memberikan bahan pelajaran, tetapi yang mengelola dan mencerna adalah peserta didik sesuai dengan kemampuan masing-masing. Ini menunjukkan bahwa yang seharusnya aktif dan mendominasi aktivitas adalah peserta didik. Piaget dalam Sardiman (2011: 100) menerangkan bahwa seorang peserta didik itu berpikir sepanjang ia berbuat. Tanpa perbuatan berarti peserta didik itu tidak berpikir. Oleh karena itu, agar peserta didik berpikir sendiri maka harus diberi kesempatan untuk berbuat sendiri. Berpikir pada taraf verbal baru akan timbul setelah peserta didik itu berpikir pada taraf perbuatan. Dengan demikian, jelas bahwa aktivitas dalam arti luas merupakan kegiatan peserta didik baik yang bersifat fisik/jasmani maupun mental/rohani. Kaitan antara keduanya akan membuahkan aktivitas belajar yang optimal. 
Berdasarkan pendapat ahli di atas, maka pembelajaran yang dilakukan antara guru dan peserta didik harus mengacu pada peningkatan aktivitas dan partisipasi peserta didik. Guru tidak hanya menyampaikan pengetahuan, keterampilan, dan sikap kepada peserta didik, tetapi juga harus mampu membawa peserta didik untuk aktif dalam berbagai kegiatan belajar. Yamin (2007: 80) menjelaskan peran aktif dan partisipasi peserta didik dalam kegiatan pembelajaran dapat dilaksanakan bila pembelajaran yang dilakukan lebih menitikberatkan pada siswa, dalam proses pembelajaran peran guru adalah sebagai pembimbing bagi siswa, tujuan kegiatan pembelajaran adalah tercapai kemampuan minimal siswa (kompetensi dasar). Pengelolaan kegiatan pembelajaran lebih menekankan pada kreativitas siswa, meningkatkan kemampuan minimalnya, dan menciptakan siswa yang kreatif serta mampu menguasai konsep-konsep. Melakukan pengukuran secara kontinu dalam berbagai aspek pengetahuan, sikap, dan keterampilan. Berdasarkan beberapa pendapat ahli mengenai pengertian aktivitas, maka dapat disimpulkan bahwa aktivitas dibutuhkan dalam proses pembelajaran karena belajar tidak akan bermakna tanpa adanya perbuatan.

Menurut McKeachie dalam Usman (2009:23), dalam mengukur kadar aktivitas siswa dalam belajar terdapat tujuh dimensi sebagai partisipasi siswa dalam menentukan tujuan kegiatan belajar mengajar, penekanan pada aspekafektif dalam pengajaran, partisipasi siswa dalam melaksanakan kegiatan belajar-mengajar, utama yang berbentuk interaksi antar siswa. Penerimaan guru terhadap perbuatan dan sumbangan siswa yang kurang relevan atau salah. Keeratan hubungan kelas sebagai kelompok. Kesempatan yang diberikan kepada siswa untuk mengambil keputusan yang penting dalam kegiatan di sekolah. Jumlah waktu yang digunakan untuk menangani masalah pribadi siswa, baik yang berhubungan ataupun yang tidak berhubungan dengan pelajaran.

Menurut Suandi (2003: 50) data aktivitas belajar siswa diambil dengan menggunakan lembar observasi, berisikan deskriptor-deskriptor dalam indikator prilaku siswa yang sudah dimodifikasi yang diamati selama proses pembelajaran berlangsung. Adapun indikator prilaku siswa yang dimaksud adalah antusiasme siswa dalam mengikuti kegiatan pembelajaran, aktivitas siswa dalam melaksanakan pembelajaran, interaksi siswa dengan guru, interaksi siswa dengan siswa, kerjasama kelompok, aktivitas siswa dalam diskusi kelompok. Indikator menurut Suandi (2003: 50) sejalan dengan tolak ukur Menurut McKeachie dalam Usman (2009:23), dalam mengukur aktivitas siswa dalam belajar.

Menurut Direktorat Pembinaan Sekolah Mengah Atas (2017: 12) penilaian hasil belajar oleh pendidik adalah proses pengumpulan informasi/data tentang capaian pembelajaran peserta didik dalam aspek sikap, pengetahuan, dan keterampilan yang dilakukan secara terencana dan sistematis. Penilaian hasil belajar oleh pendidik di SMA dilaksanakan untukmemenuhi fungsi formatif dan sumatif dalam bentuk penilaian harian dan dapat juga dilakukanpenilaian tengah semester. Penilaian tengah semester merupakan penilaian yang dilakukan oleh pendidik yang cakupan materinya terdiri atas beberapa kompetensi dasar dan pelaksanaannya tidak dikoordinasikan oleh satuan pendidikan. Penilaian harian dapat berupa ulangan, pengamatan,penugasan, dan/atau bentuk lain yang diperlukan yang digunakan untuk mengukur dan mengetahui pencapaian kompetensi peserta didik; menetapkan program perbaikan dan/atau pengayaan berdasarkan tingkat penguasaan kompetensi; memperbaiki proses pembelajaran; dan menyusun laporan kemajuan hasil belajar. Tujuan dari penelitian ini adalah meningkatkan aktivitas dan hasil belajar biologi tentang "Sel" siswa Kelas XI-MIPA di SMA Negeri 1 Kuta Selatan dengan media pembelajaran Youtobe Biologi Sel.com.

\section{Metode}

Dalam penelitian ini hasil belajar yang menjadi tolak ukur pencapaian kompetentsi pada cakupan penilaian pengetahuan dengan teknik penilaian melalui tes tulis. Data aktivitas belajar siswa diambil dengan memberikan kuesioner yang berisikan deskriptor-deskriptor dalam indikator aktivitas dengan skala sikap 5 (Skala Likert). Untuk mengetahui aktivitas siswa dalam proses pembelajaran, maka data hasil yang berupa skor diolah dengan rumus:

$$
\operatorname{skor}(x)=\frac{\left(\mathrm{n}_{1} \times 1\right)+\left(\mathrm{n}_{2} \times 2\right)+\left(\mathrm{n}_{3} \times 3\right)+\left(\mathrm{n}_{4} \times 4\right)+\left(\mathrm{n}_{5} \times 5\right)}{(\text { banyaknya siswa }) \times(\text { bany aknya item })}
$$


Keterangan:

$\mathrm{n}_{\mathrm{i}}$ = banyaknya siswa yang mendapat skor ke $\mathrm{i}$ ( untuk $\mathrm{i}=1,2,3,4,5$ ) kemudian hasilnya dibandingkan dengan kriteria seperti Tabel 3.2.

Tabel 02. Kriteria aktivitas Belajar Siswa

\begin{tabular}{cc}
\hline Skor & Katagori \\
\hline$X \geq M_{i}+1,5 S D_{i}$ & Sangat Aktif \\
$M_{i}+0,5 S D_{i}<X \leq M_{i}+1,5 S D_{i}$ & Aktif \\
$M_{i}-0,5 S D_{i}<X \leq M_{i}+0,5 S D_{i}$ & Cukup Aktif \\
$M_{i}-1,5 S D_{i}<X \leq M_{i}-0,5 S D_{i}$ & Kurang Aktif \\
$X<M_{i}-1,5 D_{i}$ & Sangat Kurang Aktif \\
\hline
\end{tabular}

(Nurkancana dan Sunartana dalam Suandi (2003))

Rumusan untuk $\mathrm{M}_{\mathrm{i}}$ dan $\mathrm{SD}_{\mathrm{i}}$ adalah

$M_{i}=1 / 2$ (skor tertinggi ideal + skor terendah ideal $)$

$S D_{i}=1 / 6$ (skor tertinggi ideal - skor terendah ideal)

Untuk aktivitas belajar siswa skor tertinggi ideal dan skor terendah ideal adalah 5 dan 1. Dengan demikian dapat dihitung mean ideal $\left(\mathrm{M}_{\mathrm{i}}\right)$ dan standar deviasi ideal $\left(\mathrm{SD}_{\mathrm{i}}\right)$ yaitu: $M_{i}=1 / 2(5+1)=1 / 2.6=3$ dan $S D_{i}=1 / 6(5-1)=1 / 6.4=0,67$. Sehingga penggolongan aktivitas belajar siswa di atas menjadi seperti tabel di bawah ini.

Tabel 03. Kriteria Penggolongan Aktivitas Belajar Siswa

\begin{tabular}{cc}
\hline Skor & Katagori \\
\hline$X \geq 4,005$ & Sangat Aktif \\
$3,335<X \leq 4,005$ & Aktif \\
$2,665<X \leq 3,335$ & Cukup Aktif \\
$1,995<X \leq 2,665$ & Kurang Aktif \\
$X<1,995$ & Sangat Kurang Aktif \\
\hline
\end{tabular}

Kriteria keberhasilan dilihat dari aktivitas belajar siswa di dalam proses pembelajaran biologi. Indikator keberhasilan ini jika tingkat aktivitas belajar siswa dalam proses belajar mengajar minimal mencapai katagori kukup aktif. Besaran nilai peserta didik ditafsirkan menurut penilaian beracuan kriteria. Melalui kriteria penilaian ini dapat diketahui tentang tingkat penguasaan (ketuntasan) peserta didik dalam menguasai KD yang telah ditetapkan. Dalam hal ini, ketuntasan belajar peserta didik ditentukan berdasarkan kriteria minimal yang ditetapkan. Penetapan nilai KKM (Kriteria Ketuntasan Minimal) kelompok mata pelajaran iptek merupakan kewenangan guru mata pelajaran yang bersangkutan. Besarnya KKM yang ideal adalah $75 \%$ (BSNP, 2010). Berdasarkan hasil analisis KKM mata pelajaraan Biologi Kelas XI Tahun Pelajaran 2017/2018 adalah 70.

$$
M=\frac{\sum \mathrm{X}}{\mathrm{N}}
$$

Keterangan

$M \quad=$ skor rata-rata

$\sum \mathrm{X} \quad=$ jumlah total skor siswa

$\mathrm{N} \quad=$ jumlah siswa

Menurut Suandi (2003:36) untuk mengetahui hasil belajar siswa, hasil tes belajar dianalisis secara deskriptif, yaitu dengan menentukan skor rata-rata hasil tes (M) dan ketuntasan klasikal (KK) dengan rumus sebagai berikut.

$$
K K=\frac{\text { bany akny asiswa y ang memperoleh nilai } \geq 70}{\text { bany akny asiswa y ang ikut tes }} \times 100 \%
$$




\section{Hasil dan Pembahasan}

Youtube.com didirikan pada Februari 2005 oleh tiga orang bekas karyawan PayPal: Chad Hurley, Steve Chen, dan Jawed Karim. Hurley pernah belajar tentang reka bentuk di Universitas Indiana Pennsylvania. Sementara itu, Chen dan Karim sama-sama belajar komputer sains di Universitas Illinois di Urbana-Champaign.(http://id.wikipedia.org/wiki/ YouTube). Youtube.com adalah sebuah situs webvideo sharing (berbagi video) populer dimana para pengguna dapat memuat, menonton, dan berbagi klip video secara gratis. Umumnya videovideo di YouTube adalah klip musik (video klip), film, TV, serta video buatan para penggunanya sendiri. Mengunduh Youtube sebagai sumber belajar Biologi dengan mengaktifkan jaringan internet kemudian melalui website :www.youtube.com kemudian ketik kata kunci "Biologi Sel" sebagai pencarian/diaktifkan file video yang akan digunakan seperti gambar berikut.

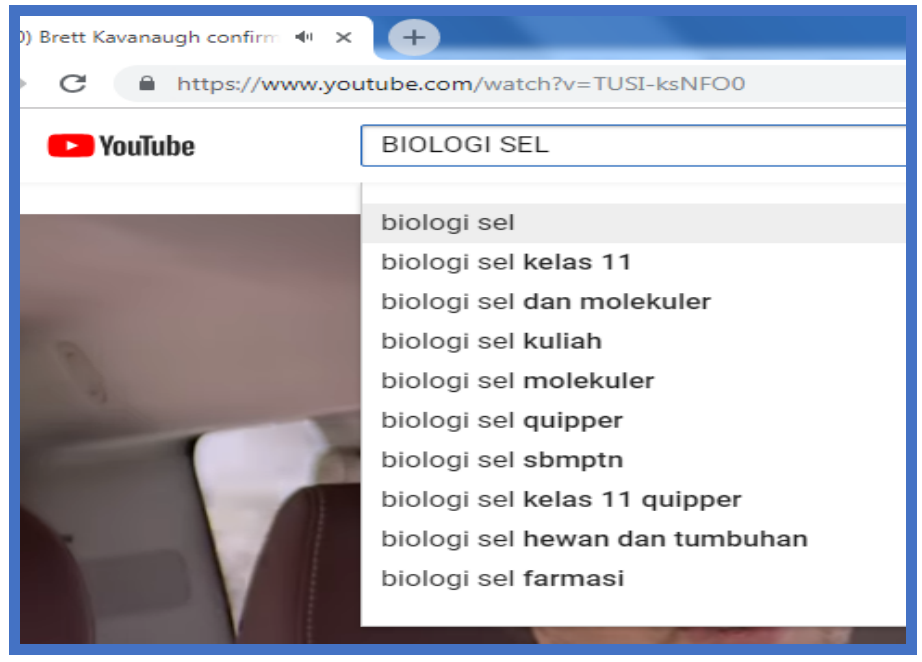

Gambar 01. Memulai Aplikasi Youtobe.com

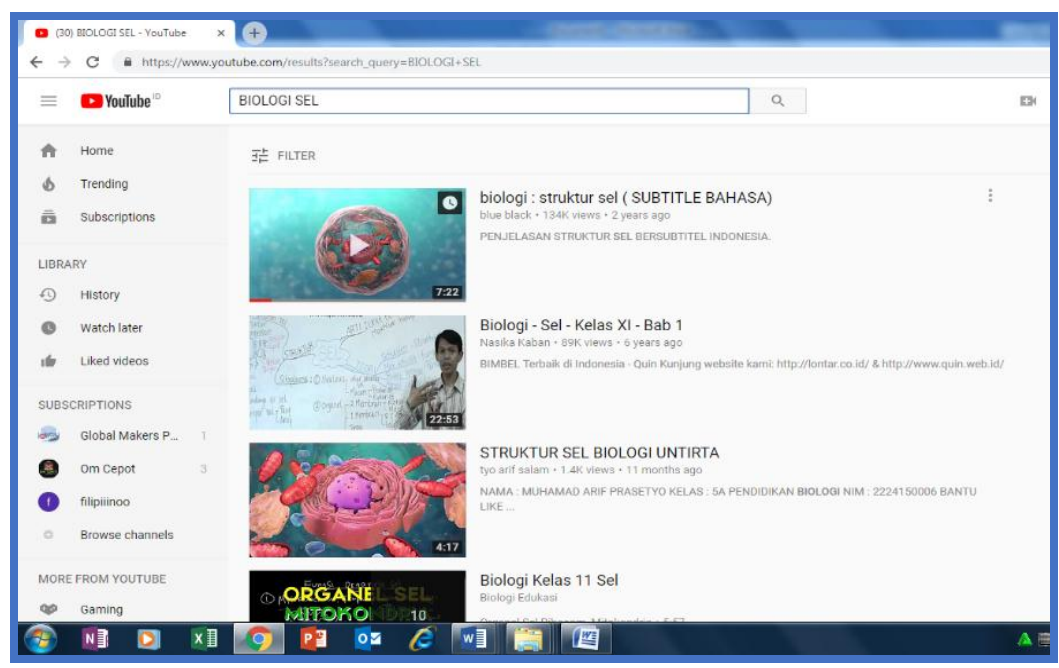

Gambar 02. Tampilan Cara Pemilihan Biologi Sel diYoutube 


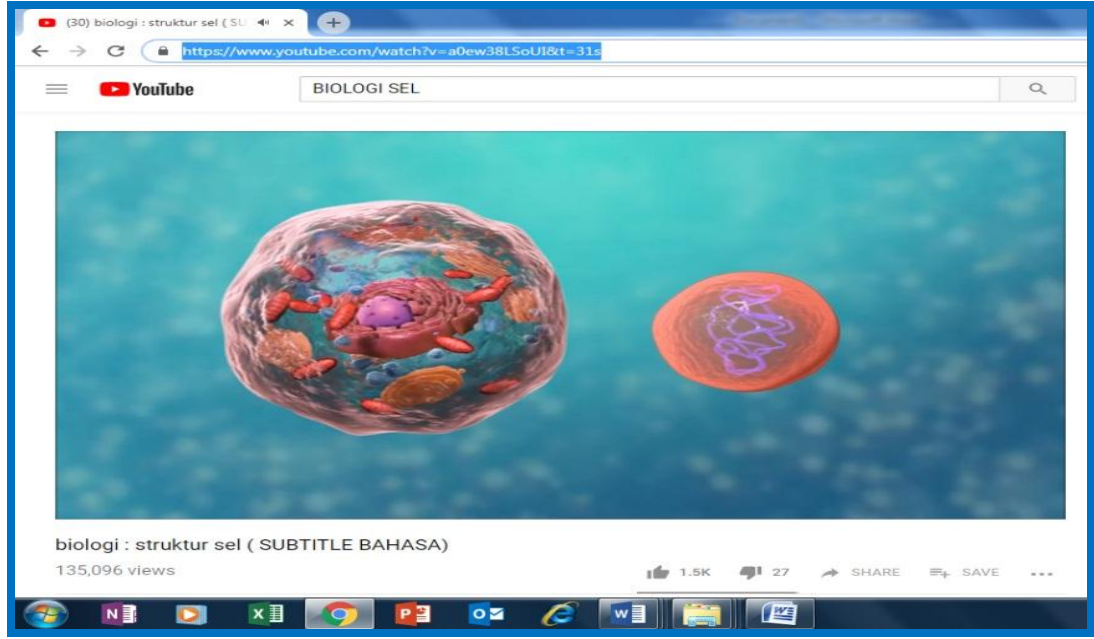

Gambar 03. Tampilan pilihan video straming Biologi Sel

Setelah pilihan video streaming Youtube Biologi Sel dipilih kemudian dilakukan perekaman dengan aplikasi "Yout.com" atau Aplikasi "All.Video" dari "Play Store" dari handphone android agar bisa digunakan dalam keadaan offline. Bila dengan menggunakan aplikasi Yout.com dengan langkah-langkah 1) blok alamat Video streaming yang akan direkam dan copy, contoh: httphttps://www.youtube. com/watch?v=a0ew38LSoUI\&t=31s, 2) aktifkan Yout.com dengan men-Tab atau tanda + (plus) pada menu Youtobe.com, kemudian ketik dan pilih Yout.com, 3)setelah tampil aplikasi Yout.com, Pastepada alamat pencarian video streaming Youtube Biologi Sel yang akan di-record . 4) tentukan jenis file dengan memilih 3 (tiga pilihan); MP3 (audio), MP4(video), GIF (Image). Kemudian pilih Record.

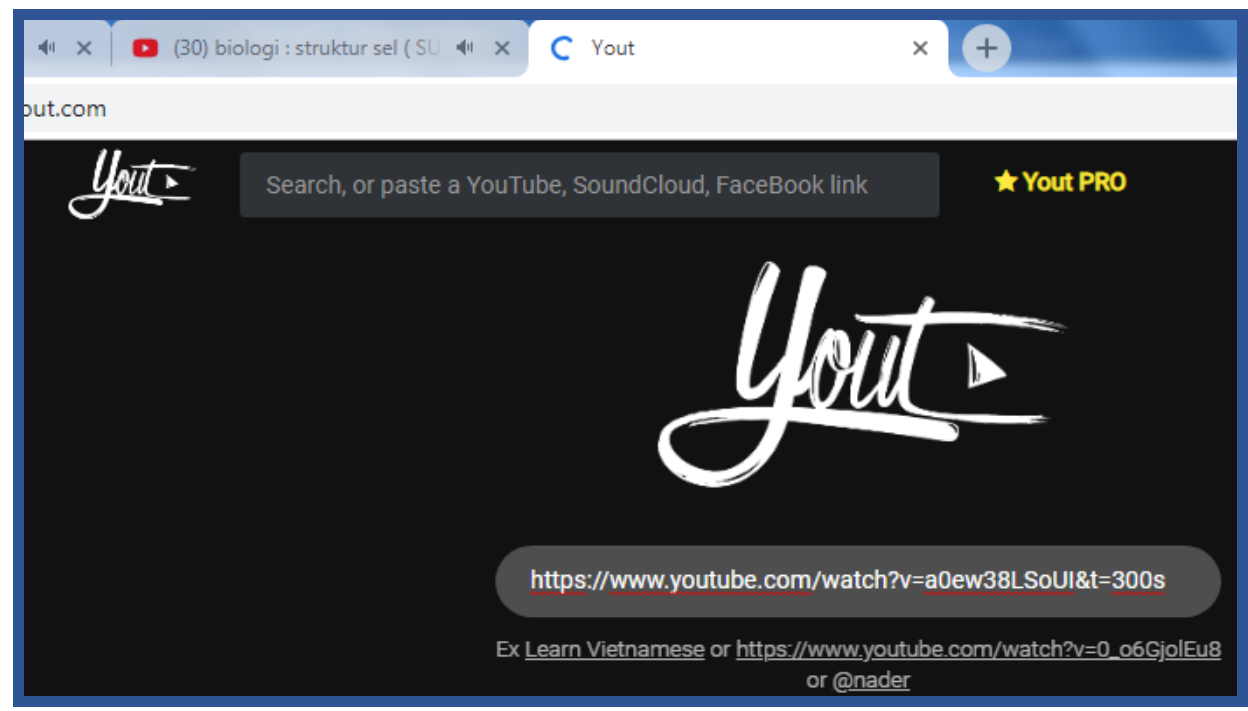

Gambar 04. Tampilan Aplikasi Yout.com

Pembelajaran dengan penggunaan media "Youtobe Biologi Sel.com" pada pembelajaran materi pokok "Sel" dengan kompetensi dasar pengetahuan; 1) Menjelaskan komponen kimiawi penyusun sel, struktur, fungsi, dan proses yang berlangsung dalam sel sebagai unit terkecil kehidupan. 2) Menganalisis berbagai bioproses dalam sel yang meliputi mekanisme transpor membran, reproduksi, dan sistesis protein, dapat mengatasi rendahnya aktivitas belajar siswa sehingga bermuara pada peningkatan prestasi hasil belajar siswa. 
Tabel 04. Aktivitas Belajar Siswa Kls. XI MIPA SMA. Negeri 1 Kuta Selatan

\begin{tabular}{|c|c|c|c|c|c|c|c|c|c|c|}
\hline \multirow[b]{2}{*}{ No } & \multirow{2}{*}{$\begin{array}{c}\text { Tahun } \\
\text { Pelajaran }\end{array}$} & \multirow[b]{2}{*}{$\begin{array}{c}\text { Kelas } \\
\text { XII }\end{array}$} & \multicolumn{5}{|c|}{ Motivasi Belajar } & \multirow{2}{*}{$\begin{array}{l}\text { Jml } \\
\text { siswa }\end{array}$} & \multirow[b]{2}{*}{ Skor } & \multirow[b]{2}{*}{ Katagori } \\
\hline & & & N1 & N2 & N3 & N4 & N5 & & & \\
\hline 1 & $2017 / 2018$ & $\begin{array}{c}\text { XI } \\
\text { MIPA } \\
7\end{array}$ & 0 & 18 & $\begin{array}{c}10 \\
9\end{array}$ & 66 & 5 & 33 & 3.29 & $\begin{array}{l}\text { Cukup } \\
\text { Aktif }\end{array}$ \\
\hline 2 & $2018 / 2019$ & $\begin{array}{c}\text { XI } \\
\text { MIPA } \\
6\end{array}$ & 0 & 18 & $\begin{array}{c}11 \\
2\end{array}$ & 81 & 5 & 36 & 3.34 & Aktif \\
\hline \multirow[t]{4}{*}{3} & $2019 / 2020$ & $\begin{array}{c}\text { XI } \\
\text { MIPA } \\
1\end{array}$ & 0 & 14 & 99 & 98 & 5 & 36 & 3.44 & Aktif \\
\hline & & $\begin{array}{c}\text { XI } \\
\text { MIPA } \\
2\end{array}$ & 0 & 13 & 95 & $\begin{array}{c}10 \\
2\end{array}$ & 6 & 36 & 3.47 & Aktif \\
\hline & & $\begin{array}{c}X I \\
\text { MIPA } \\
3\end{array}$ & 0 & 18 & $\begin{array}{c}10 \\
2\end{array}$ & 90 & 6 & 36 & 3.39 & Aktif \\
\hline & & \multicolumn{7}{|c|}{ Rerata } & 3.43 & Aktif \\
\hline
\end{tabular}

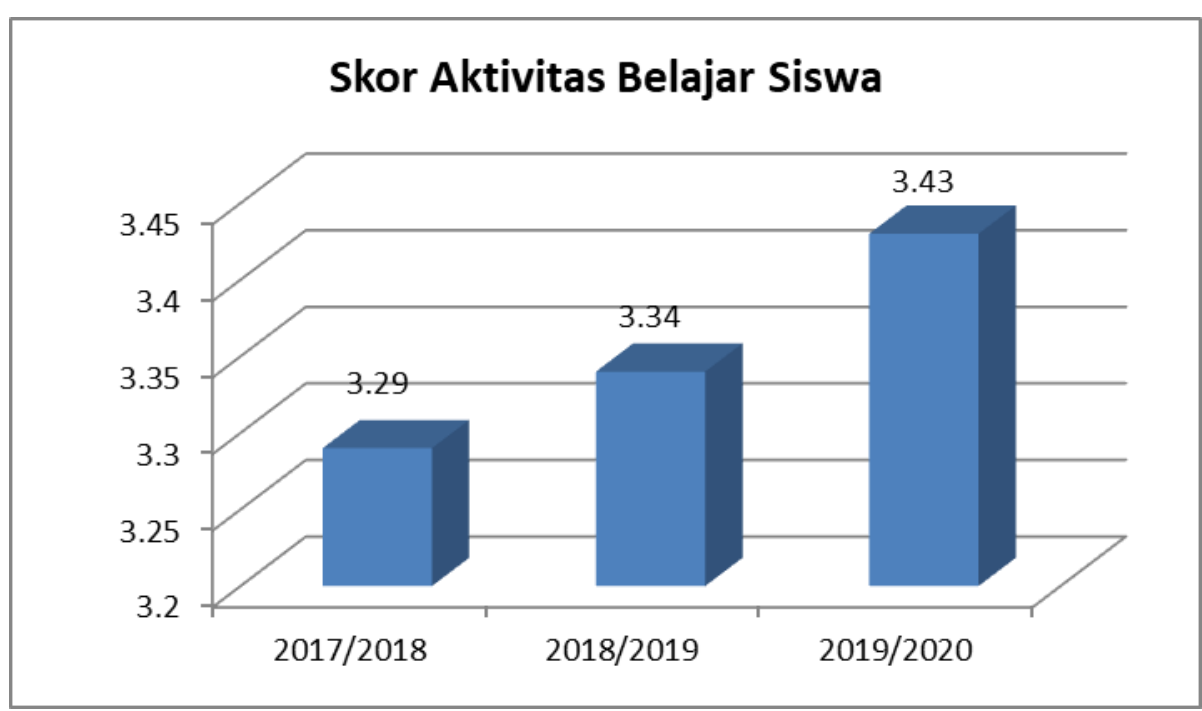

Gambar 05. Grafik Perkembangan Aktivitas Belajar

Berdasarkan tabel dan grafik diatas maka aktivitas belajar dengan penggunaan media pembelajaran Youtobe Biologi Sel.com sejak tahun pelajaran 2018/2019 sampai dengan tahun pelajaran 2019/2020 tergolong berkatagori "Aktif". Menurut Wirawan seperti dikutip Isnawati (1999: 16) mengatakan bahwa prestasi belajar adalah hasil yang telah dicapai seseorang dalam usaha belajar yang dilakukan dalam periode tertentu. Prestasi belajar dapat dipakai sebagai ukuran untuk mengetahui sejauh mana siswa dapat menguasai materi pelajaran yang telah diajarkan atau dipelajari. Sehubungan dengan itu, Masrun dan Martaniah (1974) mengatakan bahwa kegunaan prestasi belajar diantaranya adalah : (1) untuk mengetahui efisiensi hasil belajar yang dalam hal ini diharapkan mendorong siswa untuk belajar lebih giat, (2) untuk menyadarkan siswa terhadap tingkat kemampuannya ; dengan melihat hasil tes atau hasil ujiannya siswa dapat menyadari kelemahan dan kelebihannya sehingga dapat mengevaluasi dan bagaimana caranya belajar selama ini, (3) untuk petunjuk usaha belajar siswa, dan (4) untuk dijadikan dasar untuk memberikan penghargaan. Data tes hasil belajar siswa materi pokok sel disajikan pada tabel dan grafik berikut ini. 
Tabel 05. Perkembangan Nilai Hasil Belajar Materi Pokok Biologi "Sel"Kelas XI MIPA Tahun Pelajaran 2017/2018 sd. Tahun Pelajaran 2019/2020

\begin{tabular}{cccccc}
\hline No & $\begin{array}{c}\text { Tahun } \\
\text { Pelajaran }\end{array}$ & Kelas & $\begin{array}{c}\text { Nilai } \\
\text { Minimum }\end{array}$ & $\begin{array}{c}\text { Nilai } \\
\text { Maksimum }\end{array}$ & $\begin{array}{c}\text { Nilai } \\
\text { Rerata }\end{array}$ \\
\hline 1 & $2017 / 2018$ & XI MIPA7 & 67 & 95 & 89.82 \\
2 & $2018 / 2019$ & XI MIPA6 & 68 & 97.5 & 88.83 \\
& & XI MIPA1 & 70 & 98 & 90.28 \\
3 & $2019 / 2020$ & XI MIPA2 & 70 & 98 & 90.40 \\
& & XI MIPA3 & 70 & 97.5 & 90.51 \\
\cline { 3 - 6 } & & Rerata & $\mathbf{7 0}$ & $\mathbf{9 7 . 8 3}$ & $\mathbf{9 0 . 4 0}$ \\
\hline
\end{tabular}

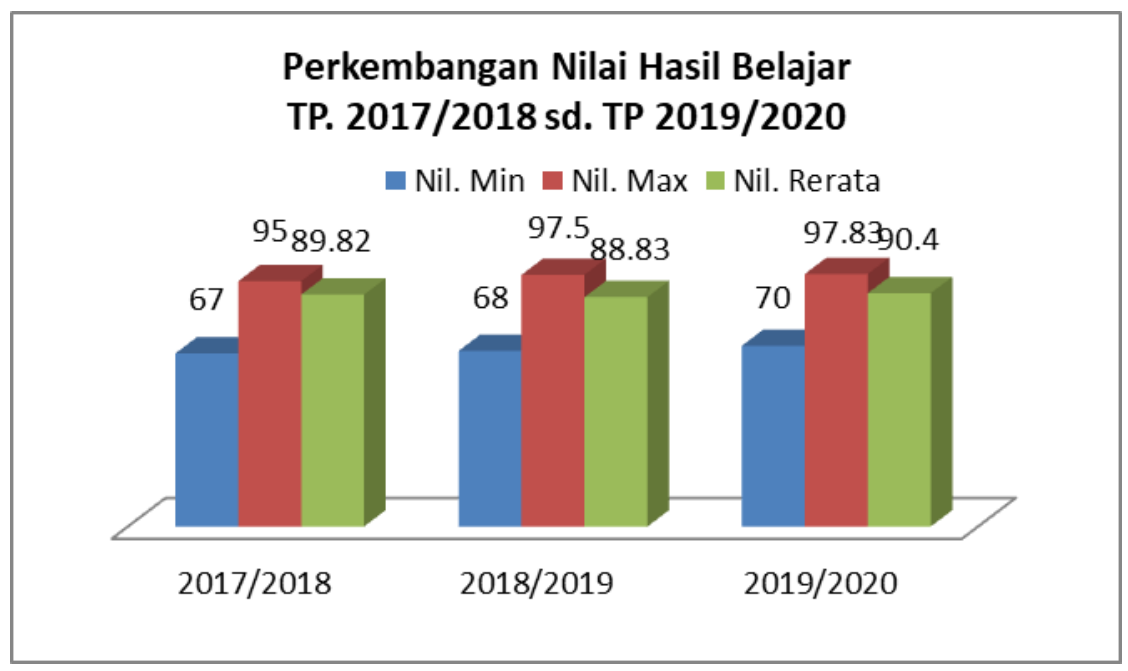

Gambar 06. Grafik Nilai Hasil Belajar Materi Pokok Biologi "Sel"Kelas XI MIPA Tahun Pelajaran 2017/2018 sd. Tahun Pelajaran 2019/2020

Berdasarkan hasil kegiatan pembelajaran mata pelajaran biologi pada materi pokok "Sel" kelas XI sejak tahun pelajaran 2017/2018 sampai dengan tahun pelajaran 2019/2020 aktivitas belajar siswa dan nilai rerata hasil belajarnya tertera dalam tabel berikut.

Tabel 6. Rekapitulasi Aktivitas Belajar dan Nilai Rerata hasil Belajar

\begin{tabular}{|c|c|c|c|c|c|}
\hline No & $\begin{array}{c}\text { Tahun } \\
\text { Pelajaran }\end{array}$ & Kelas & \multicolumn{2}{|c|}{ Aktivitas Belajar } & $\begin{array}{c}\text { Nilai Rerata } \\
\text { Hasil Belajar }\end{array}$ \\
\hline 1 & $2017 / 2018$ & XI MIPA7 & 3.29 & Cukup Baik & 87.59 \\
\hline \multirow[t]{2}{*}{2} & $2018 / 2019$ & XI MIPA6 & 3.34 & Aktif & 88.61 \\
\hline & & XI MIPA1 & 3.44 & Aktif & 90.28 \\
\hline \multirow[t]{3}{*}{3} & 2019/2020 & XI MIPA2 & 3.47 & Aktif & 90.40 \\
\hline & & XI MIPA3 & 3.39 & Aktif & 90.51 \\
\hline & & Rerata & 3.43 & Aktif & 90.40 \\
\hline
\end{tabular}

Mengamati tabel 6 di atas dapat disimpulkan bahwa melalui "Yutu Gisel" Sebagai Media Pembelajaran Untuk Meningkatkan Aktivitas Dan Hasil Belajar Biologi Sel Siswa Kelas XI MIPA Di SMA Negeri 1 Kuta Selatan. "Yutu Gisel" merupakan akronim dari "Youtube Biologi Sel.com" adalah strategi pemecahan masalah guru dengan menggunakan media pembelajaran untuk meningkatkan aktivitas dan hasil belajar biologi tentang "Sel" siswa Kelas XI-MIPA di SMA Negeri 1 Kuta Selatan. 


\section{Simpulan dan Saran}

Berdasarkan pengalaman pembelajaran dengan pemberian Youtobe Biologi Sel.com digunakan sebagai media pembelajaran kunci suksesnya adalah ; 1) adanya kesepakatan awal bersama tentang keterasediaan sarana prasarana penggunaan aplikasi Youtobe Biologi Sel. com dan cara penilaian, 2) komitmen guru dan siswa untuk melaksanakan kesepakatan bersama, 3) disiplin dalam penggunaan waktu, 4) pemberian reinforcement positif bagi siswa yang menyelesaikan tugas lebih banyak, tepat dan benar.

Sebagai tindak lanjut Youtobe Biologi.com dengan kombinasi Yout.com sebagai media pembelajaran biologi tetap dilaksanakan pada pembelajaran mendatang pula untuk kompetensi dasar biologi yang lain serta mata pelajaran lainnya sebagai adopsi dari pembelajaran "Sel".

\section{Daftar Pustaka}

BSNP. (2010). Paradigma Pendidikan Nasional Abad XXI versi 01 Tahun 2010. [Online]. Tersedia :https://akhmadsudrajat.files.wordpress.com/2013/06/paradigmapendidikannasional-abad-xxi.pdf.

Direktorat Pembinaan Sekolah Menengah Atas Direktorat Jendral Pendidikan Dasar dan Menengah Kementrian Pendidikan dan Kebudayaan, 2017. Panduan Penilaian oleh Pendidik dan Satuan Pendidikan Sekolah Menengah Atas, Kementrian Pendidikan dan Kebudayaan:Jakarta

Kusumah, Wijaya. 2010, Mengenal Penelitian Tindakan Kelas, Jakarta : PT. Indeks.

Masrun, \& Martaniah, S. M. 1974. Psikologi Pendidikan. Yogyakarta: Fakultas Psikologi UGM

Republik Indonesia., 2016. Peraturan Menteri Pendidikan dan Kebudayaan Nomor 21 Tahun 2016 tentang Standar Isi pengganti Peraturan Menteri Pendidikan dan Kebudayaan Nomor 64 Tahun 2013 : Jakarta.

Rusman, dkk. 2011. Pembelajaran Berbasis Teknologi Informasidan Komunikasi. Jakarta: PT Raja GrafindoPersada.

Sanjaya, Wina. 2009. Strategi Pembelajaran Berorientasi Standar Proses Pendidikan. Jakarta: Prenada Media Group.

Sardiman, 2011. Interaksi dan Motivasi Belajar Mengajar .Jakarta : Raja Grafindo Persada.

Suandi I Wayan, 2003. Penerapan Model Pembelajaran Kooperatif Tipe Jigsaw II Dalam Pembelajaran Bahasa Inggris Sebagi Upaya Meningkatkan Hasil Belajar Siswa Kelas III IPS 2 SMU Negeri 1 Kediri. PTK. SMU Negeri 1 Kediri. Tidak diterbitkan.

Usman, Moh. Uzer. 2009. Menjadi Guru Profesional. Bandung: RemajaRosdakarya.

Yamin, Martinis. 2007. Kiat Membelajarkan Siswa. Jakarta: Putra Grafika. 